\title{
Pengaruh Pendidikan Kewirausahaan Terhadap Niat Berwirausaha Yang Dimediasi Efikasi Diri Mahasiswa Manajemen
}

\author{
Ryan Aditya Chandra dan Herlina Budiono \\ Program Studi S1 Manajemen Fakultas Ekonomi Universitas Tarumanagara, Jakarta \\ Email: ryan.115169206@stu.untar.ac.id
}

\begin{abstract}
The purpose of this study is to explain the effect of entrepreneurship education to entrepreneurial intention mediated by self-efficacy of students on Management Department, Faculty of Economics, Universitas Tarumanagara. The subject of this study is 118 students of Entrepreneurship Concentration, Management Department, who have taken Building and Managing Entrepreneurship Business or Business Planning and Simulation course. Data are collected using a questionnaire. Data collected are analyzed using linear multiple regression analysis using IBM SPSS 23 software. The results of this study indicate that there is an effect of entrepreneurship education to entrepreneurial intention and self-efficacy. In addition, there is an effect of self-efficacy to entrepreneurial intention. Furthermore, the results of this study indicate that self-efficacy mediates the relationship between entrepreneurship education and entrepreneurial intention.
\end{abstract}

Keywords: Entrepreneurship Education, Self-Efficacy, Entrepreneurial Intention.

Abstrak: Tujuan penelitian ini adalah untuk menjelaskan pengaruh pendidikan kewirausahaan terhadap niat berwirausaha yang dimediasi efikasi diri mahasiswa Jurusan Manajemen Fakultas Ekonomi Universitas Tarumanagara. Subyek penelitian ini adalah 118 mahasiswa Jurusan Manajemen Konsentrasi Kewirausahaan dimana mereka sudah mengambil mata kuliah Membangun dan Mengelola Usaha Kewirausahaan atau Perencanaan dan Simulasi Bisnis. Data dikumpulkan dengan menggunakan kuesioner. Data yang dikumpulkan dianalisis menggunakan analisis regresi linear ganda menggunakan perangkat lunak IBM SPSS 23. Hasil penelitian ini menunjukkan terdapat pengaruh pendidikan kewirausahaan terhadap niat berwirausaha dan efikasi diri. Selain itu, terdapat pengaruh efikasi diri terhadap niat berwirausaha. Lebih lanjut lagi, hasil penelitian menunjukkan bahwa efikasi diri memediasi kaitan antara pendidikan kewirausahaan dan niat berwirausaha.

Kata kunci: Pendidikan Kewirausahaan, Efikasi Diri, Niat Berwirausaha.

\section{LATAR BELAKANG}

Indonesia merupakan negara dengan jumlah penduduk terbesar keempat di dunia setelah Tiongkok, India, dan Amerika Serikat (USCB, 2019). Di samping itu, saat ini Indonesia sedang mengalami bonus demografi dimana 69 persen dari keseluruhan 
penduduknya merupakan mereka yang sedang berada di usia produktif atau usia kerja, yaitu 15-64 tahun (Bosma dan Kelley, 2018). Apabila kondisi tersebut dapat dimanfaatkan dengan baik, jumlah pendapatan populasi yang produktif akan mengalami peningkatan sehingga mendorong investasi yang pada akhirnya akan mendorong pertumbuhan ekonomi (Hendratno dan Fitriati, 2015).

Meskipun demikian, Pemerintah masih belum mampu memanfaatkan bonus demografi yang dimiliki Indonesia dengan maksimal. Hal ini ditandai dengan masih cukup tingginya angka pengangguran di Indonesia. Data dari Badan Pusat Statistik tahun 2018 menunjukkan bahwa jumlah angkatan kerja pada bulan Agustus 2018 mencapai 131,01 juta orang dengan tingkat pengangguran terbuka sebesar 5,34 persen atau 7 juta orang. Tingkat pengangguran Indonesia berada di urutan kedua tertinggi di Asia Tenggara setelah Brunei Darussalam.

Data Badan Pusat Statistik (2018) juga menunjukkan bahwa pengangguran didominasi oleh penduduk yang berasal dari kelompok usia muda, yaitu penduduk yang berusia 15 hingga 24 tahun, dimana tingkat pengangguran kelompok usia 15-19 tahun mencapai 26,67 persen dan tingkat pengangguran kelompok usia 20-24 tahun mencapai 16,73 persen. Selain itu, data Badan Pusat Statistik pada bulan Agustus 2018 menunjukkan bahwa sebanyak 729.601 orang atau 10,42 persen orang yang menganggur merupakan lulusan universitas. Sebanyak 220.932 orang atau 3,16 persen orang yang menganggur merupakan lulusan akademi atau diploma.

Data tersebut cukup memprihatinkan dan menunjukkan bahwa pendidikan tinggi yang ditempuh seseorang tidak menjamin sepenuhnya bahwa mereka akan memiliki pekerjaan setelah menyelesaikan pendidikannya. Pemerintah masih kesulitan untuk memastikan kaum muda dapat diserap lapangan pekerjaan yang tersedia meskipun Pemerintah telah mengupayakan peningkatan partisipasi mereka dalam mengeyam pendidikan (IBRD - World Bank, 2018).

Berbagai upaya dilakukan oleh Pemerintah untuk mengurangi tingkat pengangguran, seperti meningkatkan kualitas pendidikan umum, pendidikan vokasi, dan pelatihan; mengembangkan layanan dan informasi pasar tenaga kerja yang lebih baik; hingga menyusun program untuk mencocokkan penawaran tenaga kerja dengan kebutuhan industri. Pemerintah juga berupaya untuk mendorong penciptaan lapangan pekerjaan melalui kewirausahaan dimana kaum muda masih membutuhkan banyak dorongan untuk meniti karier di bidang kewirausahaan. Namun, karier kewirausahaan tidak dipertimbangkan secara serius sebagai jalur karier yang menarik di kalangan kaum muda Indonesia. Hal ini dikarenakan pola pikir kaum muda yang masih memiliki kecenderungan sebagai pencari kerja daripada sebagai pencipta lapangan pekerjaan. Selain itu, karier kewirausahaan masih cenderung tidak disarankan oleh orang tua (ILO, 2016).

Untuk mendukung aktivitas kewirausahaan, Pemerintah membuat sejumlah kebijakan, seperti bantuan modal usaha bagi wirausahawan pemula, peningkatan akses pasar, hingga program pelatihan dan pendidikan kewirausahaan. Dalam pendidikan kewirausahaan, siswa akan diberikan pelajaran kewirausahaan untuk mengajarkan caracara berwirausaha yang pada akhirnya akan membangun budaya kewirausahaan dalam institusi pendidikan. Melalui program tersebut, Pemerintah berharap agar setelah lulus, siswa dapat langsung membuka usaha sendiri (Festiani, 2015; Wardi, 2018).

Institusi pendidikan memiliki peran penting dalam pengembangan kewirausahaan untuk mendukung kualitas dan pertumbuhan kewirausahaan yang berkelanjutan di negara 
berkembang (GERA, 2018). Hal ini dikarenakan pendidikan kewirausahaan dapat meningkatkan efikasi diri siswa melalui ketersediaan pengetahuan dan kemampuan yang dibutuhkan untuk memulai bisnis yang pada akhirnya akan mempengaruhi niat siswa untuk berwirausaha (Hasan et al., 2017).

Salah satu institusi pendidikan tinggi yang menekankan nilai-nilai kewirausahaan dan mengembangkan pendidikan kewirausahaan dalam kurikulum pendidikannya adalah Universitas Tarumanagara. Universitas Tarumanagara menekankan nilai-nilai integritas, profesional, dan entrepreneurship (IPE) dalam pendidikannya. Hal ini terlihat dari visi Universitas Tarumangara, yaitu "Menjadi Universitas Entrepreneurial Unggul yang memiliki Integritas dan Profesionalisme di Asia Tenggara". Visi tersebut didukung dengan adanya berbagai kegiatan yang dilakukan untuk membangun budaya kewirausahaan di lingkungan universitas, seperti pelatihan dan seminar kewirausahaan, studi banding, program mahasiswa berwirausaha, dan yang lainnya. Hal ini diperkuat dengan adanya mata kuliah Dasar-dasar Kewirausahaan yang wajib diambil oleh seluruh mahasiswa. Secara lebih spesifik, Jurusan Manajemen Universitas Tarumanagara memiliki konsentrasi kewirausahaan yang dapat diambil oleh mahasiswa. Mahasiswa yang mengambil konsentrasi kewirausahaan akan memperoleh ilmu yang lebih dalam dan pengalaman yang lebih luas di bidang kewirausahaan. Mahasiswa dapat merasakan proses kewirausahaan dimulai dari perencanaan ide bisnis hingga implementasinya melalui berbagai mata kuliah dan kegiatan Entrepreneur Week yang secara rutin diselenggarakan setiap semester.

Melihat uraian di atas, peneliti melakukan penelitian dengan judul "Pengaruh Pendidikan Kewirausahaan terhadap Niat Berwirausaha yang Dimediasi Efikasi Diri Mahasiswa Jurusan Manajemen Fakultas Ekonomi Universitas Tarumanagara”.

\section{KAJIAN TEORI}

Kewirausahaan merupakan proses dinamis dari pencapaian visi, perubahan, dan penciptaan yang membutuhkan energi dan gairah terhadap penciptaan dan implementasi ide yang baru dan solusi yang kreatif (Kuratko, 2009). Kewirausahaan melibatkan tindakan, dimana individu menggunakan pengetahuan dan motivasi mereka sebelum bertindak dengan melihat peluang yang ada (Hisrich et al., 2013).

Salah satu teori yang dapat menjelaskan bagaimana seseorang melakukan suatu tindakan, termasuk tindakan kewirausahaan, adalah the Theory of Planned Behavior. Ajzen (1985) dalam the Theory of Planned Behavior menjelaskan bahwa tindakan dan perilaku yang dilakukan seseorang merupakan aktivitas yang disengaja dimana tindakan tersebut diawali oleh niat yang dibangun untuk melakukan tindakan dan perilaku tersebut. Tapi, tidak semua niat berlanjut menjadi suatu tindakan. Beberapa niat tidak jadi dilakukan sementara beberapa niat yang lain diperbaiki dan diperbaharui sehingga sesuai dengan situasi yang berubah.

Berdasarkan the Theory of Planned Behavior, niat berwirausaha didefinisikan sebagai usaha yang akan dilakukan seseorang untuk memulai dan terlibat dalam perilaku kewirausahaan serta melakukan aktivitas kewirausahaan dimana niat tersebut dapat dipengaruhi oleh beberapa faktor, seperti kebutuhan, nilai, keinginan, dan kepercayaan. (Paul et al., 2017). Tindakan kewirausahaan sering kali diawali dengan niat untuk mengejar peluang kewirausahaan, memasuki pasar baru, dan menawarkan produk baru. 
Niat kewirausahaan menangkap faktor motivasi yang mempengaruhi perilaku seseorang (Hisrich et al., 2013).

Paul et al. (2017) menjelaskan bahwa terdapat tiga faktor motivasi yang mempengaruhi perilaku dan niat berwirausaha seseorang, yaitu attitude towards entrepreneurship yang merupakan tingkat penilaian pribadi seseorang, baik penilaian yang positif maupun negatif, mengenai perilaku dan tindakan menjadi seorang wirausahawan; subjective norm yang merupakan tekanan sosial yang diterima ataupun tidak diterima yang berhubungan dengan aktivitas kewirausahaan; dan perceived behavioral control yang merupakan persepsi kemudahan atau kesulitan seseorang menjadi wirausahawan.

Azjen (1991) menjelaskan bahwa perceived behavioral control merupakan faktor yang memiliki peran yang penting dalam the Theory of Planned Behavior. Lebih lanjut lagi, Azjen (1991) menjelaskan bahwa konsep perceived behavioral control memiliki kesamaan dengan konsep perceived self-efficacy oleh Bandura (1982, 1991). Efikasi diri merupakan keyakinan seseorang mengenai kemampuan mereka untuk memegang kendali atas aktivitas mereka sendiri dan kendali atas kegiatan yang mempengaruhi hidup mereka dimana efikasi diri akan mempengaruhi pilihan aktivitas dan tindakan seseorang, persiapan untuk aktivitas tersebut, besarnya usaha yang akan dikeluarkan selama bertindak, pola pemikiran, serta reaksi emosional (Azjen, 1991; Fayolle et al., 2006).

Entrepreneurial Intention Model dengan menggunakan the Theory of Planned Behavior telah digunakan untuk pendidikan dan pelatihan kewirausahaan (Fayolle et al., 2006). Krueger dan Carsrud (1993) menjelaskan bahwa program pendidikan dapat berpengaruh terhadap niat berwirausaha yang dapat diidentifikasi oleh the Theory of Planned Behavior dimana perceived self-efficacy dipengaruhi oleh akuisisi alat manajemen dan pemahaman terhadap situasi kewirausahaan.

Puni et al. (2018) memaparkan bahwa dalam pendidikan kewirausahaan, siswa akan memperoleh kemampuan mengidentifikasi peluang. Pendidikan kewirausahaan memiliki pengaruh yang positif pada kesempatan seseorang untuk menemukan peluang baru. Selain itu, pendidikan kewirausahaan juga akan memberikan pengetahuan kewirausahaan kepada siswa. Pendidikan dan pengalaman kewirausahaan menyediakan pengetahuan, kemampuan, dan keahlian pemecahan masalah untuk berbagai macam situasi. Pendidikan kewirausahaan dapat memfasilitasi proses pemahaman pengetahuan baru yang pada akhirnya akan memberikan seseorang kemampuan yang lebih baik untuk melihat lebih banyak peluang dan membantu seseorang untuk beradaptasi dengan situasi yang baru (Hisrich et al., 2013).

Model penelitian ini dapat digambarkan sebagai berikut:

Gambar 1. Model Penelitian

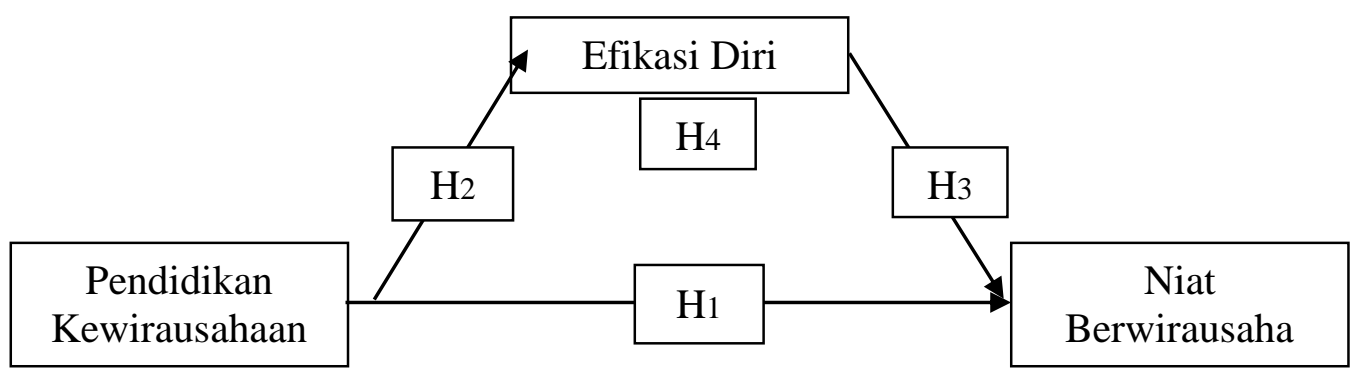


Berdasarkan model penelitian di atas, hipotesis dari penelitian ini adalah sebagai berikut:

H1: Terdapat pengaruh pendidikan kewirausahaan terhadap niat berwirausaha mahasiswa Jurusan Manajemen Fakultas Ekonomi Universitas Tarumanagara.

H2: Terdapat pengaruh pendidikan kewirausahaan terhadap efikasi diri mahasiswa Jurusan Manajemen Fakultas Ekonomi Universitas Tarumanagara.

H3 : Terdapat pengaruh efikasi diri terhadap niat berwirausaha mahasiswa Jurusan Manajemen Fakultas Ekonomi Universitas Tarumanagara.

H4: Efikasi diri akan memediasi kaitan antara pendidikan kewirausahaan dan niat berwirausaha mahasiswa Jurusan Manajemen Fakultas Ekonomi Universitas Tarumanagara.

\section{METODOLOGI}

Aritonang R. (2007) menjelaskan bahwa dalam arti yang sempit, desain penelitian terdiri atas penentuan subyek penelitian, pengembangan instrumen penelitian, perolehan data empiris, persiapan analisis, dan analisis data. Sementara dalam arti yang luas, desain penelitian merupakan semua rencana pelaksanaan penelitian, mulai dari identifikasi permasalahan hingga kegiatan paling akhir dalam suatu penelitian.

Penelitian ini merupakan penelitian yang bersifat deskriptif, yaitu penelitian yang bertujuan untuk menguji kebenaran empiris dari hipotesis penelitian mengenai kaitan antar dua atau lebih variabel penelitian. Penelitian deskriptif dilakukan melalui pengumpulan data kuantitatif yang kemudian dianalisis dengan menggunakan teknik analisis untuk data kuantitatif (Aritonang R., 2007). Penelitian ini menggunakan desain studi cross-sectional, yaitu penelitian dimana variabel pada penelitian tersebut diukur sebanyak satu kali pada waktu yang relatif bersamaan (Aritonang R., 2007).

Populasi yang digunakan sebagai subyek dalam penelitian ini adalah mahasiswa Jurusan Manajemen Fakultas Ekonomi Universitas Tarumanagara. Desain pengambilan sampel yang digunakan dalam penelitian ini adalah desain pengambilan sampel nonprobabilitas, yaitu desain pengambilan sampel dimana setiap unsur populasi tidak memiliki probabilitas yang sama untuk terpilih sebagai sampel penelitian (Aritonang R., 2007). Teknik pengambilan sampel yang digunakan dalam penelitian ini adalah teknik pengambilan sampel bertujuan (purposive sampling), yaitu teknik pengambilan sampel dimana unsur populasi yang terpilih menjadi sampel didasarkan pada tujuan penelitian dan digunakan apabila karakteristik populasi penelitian telah diketahui (Aritonang R., 2007). Sampel dalam penelitian ini adalah 118 mahasiswa Jurusan Manajemen Fakultas Ekonomi Universitas Tarumanagara yang mengambil konsentrasi kewirausahaan dan sudah mengambil mata kuliah Membangun dan Mengelola Usaha Kewirausahaan atau Perencanaan dan Simulasi Bisnis.

Data yang digunakan dalam penelitian ini merupakan data primer (primary data), yaitu informasi dan data yang diperoleh secara langsung oleh peneliti berhubungan dengan variabel yang diuji untuk tujuan tertentu dari penelitian (Sekaran dan Bougie, 2017). Kuesioner digunakan sebagai instrumen untuk memperoleh data empiris pada penelitian ini karena kuesioner dapat diadministrasikan sekaligus pada sejumlah besar subyek penelitian (Aritonang R., 2007).

Variabel pendidikan kewirausahaan diukur dengan menggunakan 9 item yang diadopsi dari Puni et al. (2018), variabel efikasi diri diukur dengan menggunakan 21 item 
yang diadopsi dari Puni et al. (2018) serta Herath dan Rosli (2014), sementara variabel niat berwirausaha diukur dengan menggunakan 6 item yang diadopsi dari Puni et al. (2018) dan Liñán dan Chen (2009).

Penelitian ini menggunakan skala likert untuk mengelompokkan jawaban responden. Skala likert dalam penelitian ini dinyatakan dalam lima keategori, yaitu (1) sangat tidak setuju, (2) tidak setuju, (3) netral, (4) setuju, (5) sangat setuju. Joshi et al. (2015) menjelaskan bahwa skala likert merupakan skala interval apabila penelitian menggabungkan beberapa item untuk menghasilkan skor komposit atau skor total dari item-item tersebut dan data yang dikumpulkan dianalisis dengan menggunakan analisis parametrik.

Dalam penelitian ini, pengujian dan analisis data dilakukan dengan menggunakan perangkat lunak IBM SPSS 23.

\section{HASIL ANALISIS DATA}

Uji validitas dilakukan dengan membandingkan nilai $\mathrm{r}$ hitung dalam kolom Corrected Item - Total Correlation pada output Cronbach's Alpha dengan nilai r tabel. Suatu item dikatakan valid apabila memiliki nilai $r$ hitung yang lebih besar daripada nilai $r$ tabel dan $r$ hitung bernilai positif (Ghozali, 2013). Hasil pengujian menunjukkan bahwa semua item dalam penelitian ini memiliki nilai $r$ hitung lebih besar daripada $r$ tabel $(0,181)$. Dengan demikian, semua item dalam penelitian ini adalah valid.

Uji reliabilitas dilakukan dengan menggunakan Cronbach's Alpha. Suatu variabel dikatakan reliabel apabila memiliki nilai Cronbach's Alpha minimal 0,700 (Ghozali, 2013). Hasil pengujian menunjukkan bahwa nilai Cronbach's Alpha variabel pendidikan kewirausahaan dimensi kemampuan mengidentifikasi peluang adalah 0,709, nilai Cronbach's Alpha variabel pendidikan kewirausahaan dimensi akuisisi pengetahuan kewirausahaan adalah 0,759, nilai Cronbach's Alpha variabel efikasi diri adalah 0,937, dan nilai Cronbach's Alpha variabel niat berwirausaha adalah 0,846. Dengan demikian, semua variabel dalam penelitian ini adalah reliabel.

Penelitian ini menggunakan dua model regresi. Model regresi 1 adalah model regresi yang menggunakan variabel pendidikan kewirausahaan dimensi kemampuan mengidentifikasi peluang sebagai variabel independen, efikasi diri sebagai variabel mediator, dan niat berwirausaha sebagai variabel dependen. Sementara itu, model regresi 2 adalah model regresi yang menggunakan variabel pendidikan kewirausahaan dimensi akuisisi pengetahuan kewirausahaan sebagai variabel independen, efikasi diri sebagai variabel mediator, dan niat berwirausaha sebagai variabel dependen. Peneliti menggunakan dua model regresi untuk membandingkan pengaruh pendidikan kewirausahaan dimensi kemampuan mengidentifikasi peluang yang merupakan soft skill serta pendidikan kewirausahaan dimensi akuisisi pengetahuan kewirausahaan yang merupakan hard skill terhadap niat berwirausaha mahasiswa.

Uji multikolinearitas dilakukan dengan membandingkan nilai tolerance dan nilai VIF dengan cut-off point. Suatu model regresi terindikasi memiliki multikolinearitas apabila nilai tolerance $\leq 0,10$ dan nilai VIF $\geq 10$ (Ghozali, 2013). Hasil pengujian menunjukkan bahwa model regresi 1 tidak memiliki multikolinearitas karena model regresi 1 memiliki nilai tolerance 0,656 dan nilai VIF 1,524. Hasil penelitian juga menunjukkan bahwa model 
regresi 2 tidak memiliki multikolinearitas karena model regresi 2 memiliki nilai tolerance 0,475 dan nilai VIF 2,104.

Hasil uji heteroskedastisitas dalam model regresi 1 dan 2 menunjukkan tidak terdapatnya pola yang jelas dan teratur dalam grafik plot serta titik-titik cenderung menyebar di atas dan di bawah angka nol pada sumbu Y dalam grafik plot. Dengan demikian, dapat disimpulkan bahwa tidak terjadi heteroskedastisitas dalam model regresi 1 dan 2.

Uji normalitas dilakukan dengan menggunakan uji Kolmogorov-Smirnov. Suatu model regresi dapat dikatakan berdistribusi normal apabila nilai asymp. sig. > 0,05 (Ghozali, 2013). Hasil pengujian menunjukkan bahwa model regresi 1 dan 2 memiliki nilai asymp. sig. sebesar 0,200. Dengan demikian, dapat disimpulkan bahwa kedua model regresi memenuhi persyaratan normalitas.

Hasil analisis koefisien determinasi model regresi 1 menunjukkan nilai $\mathrm{R}^{2}$ sebesar 0,311 . Sementara itu, hasil analisis koefisien determinasi model regresi 2 menunjukkan nilai $\mathrm{R}^{2}$ sebesar 0,304 .

Pengujian hipotesis dengan uji t dilakukan untuk menguji pengaruh satu variabel independen secara individual terhadap variabel dependen. Pengujian hipotesis dilakukan dengan membandingkan nilai p-value dengan tingkat kepercayaan $(\alpha)$ sebesar 0,05 . Koefisien regresi adalah signifikan apabila nilai $p$-value $<0,05$ (Ghozali, 2013).

Hasil pengujian H1 untuk menguji pengaruh pendidikan kewirausahaan terhadap niat berwirausaha dalam model regresi 1 dan 2 menunjukkan nilai p-value sebesar 0,000. Dengan demikian, dapat disimpulkan bahwa $\mathrm{H} 1$ tidak ditolak.

Hasil pengujian $\mathrm{H} 2$ untuk menguji pengaruh pendidikan kewirausahaan terhadap efikasi diri dalam model regresi 1 dan 2 menunjukkan nilai $p$-value sebesar 0,000. Dengan demikian, dapat disimpulkan bahwa $\mathrm{H} 2$ tidak ditolak.

Hasil pengujian $\mathrm{H} 3$ untuk menguji pengaruh efikasi diri terhadap niat berwirausaha menunjukkan nilai p-value sebesar 0,000. Dengan demikian, dapat disimpulkan bahwa H3 tidak ditolak.

Pengujian mediasi dilakukan untuk mengetahui apakah suatu variabel ikut mempengaruhi kaitan antara variabel independen dengan variabel dependen. Suatu variabel dapat dikatakan sebagai mediator apabila memenuhi tiga kondisi, yaitu variabel independen mempengaruhi variabel dependen secara signifikan, variabel independen mempengaruhi variabel mediator secara signifikan, serta variabel mediator mempengaruhi variabel dependen secara signifikan dengan mengontrol variabel independen (Ghozali, 2013). Hasil pengujian hipotesis $\mathrm{H} 1, \mathrm{H} 2$, dan $\mathrm{H} 3$ menunjukkan bahwa model regresi 1 dan 2 memenuhi ketiga kondisi tersebut.

Uji mediasi dilakukan dengan menggunakan uji Sobel. Pengujian hipotesis dilakukan dengan membandingkan nilai $p$-value dengan tingkat kepercayaan $(\alpha)$ sebesar 0,05 . Apabila nilai $p$-value $<0,05$, maka koefisien mediasi adalah signifikan dan menunjukkan adanya mediasi (Ghozali, 2013). Hasil pengujian H4 untuk menguji mediasi menunjukkan bahwa model regresi 1 dan 2 memiliki nilai p-value sebesar 0,000. Dengan demikian, dapat disimpulkan bahwa $\mathrm{H} 4$ tidak ditolak. 


\section{DISKUSI}

Hasil analisis koefisien determinasi model regresi 1 menunjukkan nilai $\mathrm{R}^{2}$ sebesar 0,311 . Artinya, variabel niat berwirausaha dapat dijelaskan oleh variabel pendidikan kewirausahaan dimensi kemampuan mengidentifikasi peluang dan efikasi diri sebesar 31,10 persen sementara sisanya sebesar 68,90 persen dijelaskan oleh variabel lain, seperti latar belakang keluarga, sikap terhadap kewirausahaan, norma subyektif, dan perilaku.

Sementara itu, hasil analisis koefisien determinasi model regresi 2 menunjukkan nilai $\mathrm{R}^{2}$ sebesar 0,304. Artinya, variabel niat berwirausaha dapat dijelaskan oleh variabel pendidikan kewirausahaan dimensi akuisisi pengetahuan kewirausahaan dan efikasi diri sebesar 30,40 persen sementara sisanya sebesar 69,60 persen dijelaskan oleh variabel lain, seperti latar belakang keluarga, sikap terhadap kewirausahaan, norma subyektif, dan perilaku.

Hasil pengujian uji t pada model regresi 1 dan 2 menunjukkan bahwa $\mathrm{H} 1$ tidak ditolak. Dengan demikian, dapat disimpulkan bahwa terdapat pengaruh pendidikan kewirausahaan terhadap niat berwirausaha mahasiswa Jurusan Manajemen Fakultas Ekonomi Universitas Tarumanagara dengan tingkat keyakinan 95 persen. Puni et al. (2018) menjelaskan bahwa akuisisi atas pengetahuan kewirausahaan dan pengembangan kemampuan mengidentifikasi peluang yang dipelajari melalui pendidikan kewirausahaan dapat meningkatkan niat berwirausaha mahasiswa. Hal ini karena kedua hal yang diperoleh melalui pendidikan kewirausahaan tersebut merupakan salah satu sumber daya penting bagi mahasiswa dalam melakukan aktivitas kewirausahaan

Hasil pengujian uji t pada model regresi 1 dan 2 menunjukkan bahwa $\mathrm{H} 2$ tidak ditolak. Sehingga, dapat disimpulkan bahwa terdapat pengaruh pendidikan kewirausahaan terhadap efikasi diri mahasiswa Jurusan Manajemen Fakultas Ekonomi Universitas Tarumanagara.dengan tingkat keyakinan 95 persen. Pendidikan kewirausahaan dapat meningkatkan kepercayaan diri mahasiswa agar dapat berhasil dalam melakukan aktivitas kewirausahaan (Puni et al., 2018).

Sementara itu, hasil pengujian uji t pada model regresi 1 dan 2 menunjukkan bahwa H3 tidak ditolak. Dengan demikian, dapat disimpulkan bahwa terdapat pengaruh efikasi diri terhadap niat berwirausaha mahasiswa Jurusan Manajemen Fakultas Ekonomi Universitas Tarumanagara dengan tingkat keyakinan 95 persen. Yadav (2017) menjelaskan bahwa level efikasi diri mahasiswa merupakan faktor yang kuat dalam menentukan minat mereka untuk menjadi wirausahawan setelah menyelesaikan pendidikan.

Hasil pengujian mediasi pada model regresi 1 dan 2 menunjukkan bahwa $\mathrm{H} 4$ tidak ditolak. Sehingga, dapat disimpulkan bahwa efikasi diri akan memediasi kaitan antara pendidikan kewirausahaan dan niat berwirausaha mahasiswa Jurusan Manajemen Fakultas Ekonomi Universitas Tarumanagara dengan tingkat keyakinan 95 persen. Pendidikan kewirausahaan akan mengembangkan efikasi diri mahasiswa dengan menciptakan kesadaran dan kepercayaan diri akan kemampuan yang dimiliki untuk menjalankan aktivitas kewirausahaan yang pada akhirnya akan mempengaruhi niat berwirausaha mahasiswa (Puni, et al., 2018). 


\section{KESIMPULAN}

Berdasarkan hasil pengujian tersebut, maka dapat disimpulkan bahwa terdapat pengaruh pendidikan kewirausahaan terhadap niat berwirausaha mahasiswa Jurusan Manajemen Fakultas Ekonomi Universitas Tarumanagara, terdapat pengaruh pendidikan kewirausahaan terhadap efikasi diri mahasiswa Jurusan Manajemen Fakultas Ekonomi Universitas Tarumanagara, terdapat pengaruh efikasi diri terhadap niat berwirausaha mahasiswa Jurusan Manajemen Fakultas Ekonomi Universitas Tarumanagara, serta efikasi diri akan memediasi kaitan antara pendidikan kewirausahaan dan niat berwirausaha mahasiswa Jurusan Manajemen Fakultas Ekonomi Universitas Tarumanagara.

Keterbatasan dalam penelitian ini adalah waktu yang tersedia dalam penelitian ini terbatas sehingga penelitian ini hanya dilakukan pada ruang lingkup yang sempit, yaitu Jurusan Manajemen Fakultas Ekonomi Universitas Tarumanagara. Sampel yang diambil hanya berasal dari mahasiswa yang mengambil konsentrasi kewirausahaan sehingga hasil penelitian ini belum tentu sama dengan hasil penelitian di konsentrasi dan jurusan lain. Selain itu, hasil penelitian ini belum bisa digeneralisasikan untuk ruang lingkup yang lebih besar. Penelitian ini hanya menggunakan variabel pendidikan kewirausahaan dan efikasi diri yang mempengaruhi niat berwirausaha mahasiswa.

Berdasarkan hasil penelitian ini, maka beberapa saran yang dapat diberikan oleh peneliti adalah sebagai berikut: (1) Mahasiswa perlu dilatih dan didorong untuk memahami berbagai permasalahan yang ada di masyarakat dan menghadirkan solusi inovatif atas berbagai permasalahan tersebut. (2) Pendidikan kewirausahaan perlu menginformasikan berbagai alternatif sumber daya untuk mendanai pembentukan bisnis baru. Universitas dapat mengadakan kegiatan seminar yang menghadirkan investor ataupun perusahaan yang menyediakan dana untuk wirausahawan baru. Mahasiswa juga perlu dilatih untuk meyakinkan investor dan mengembangkan hubungan yang baik dengan investor. (3) Universitas dapat lebih sering mengadakan kuliah tamu ataupun sesi mentoring dengan menghadirkan wirausahawan sehingga mahasiswa dapat memahami proses kewirausahaan di dunia nyata, mengidentifikasi karakteristik wirausahawan dan proses yang diperlukan agar menjadi sukses, dan termotivasi untuk menjadi seorang wirausahawan. Kegiatan ini dapat mengembangkan soft skill untuk melengkapi pengetahuan teoritis yang sudah diperoleh di perkuliahan. (4) Pihak universitas dapat mengembangkan inkubator bisnis untuk membina mahasiswa dalam mengembangkan bisnis yang potensial. Selain itu, inkubator bisnis juga dapat menjembatani mahasiswa dengan sumber pendanaan potensial. (5) Pada penelitian selanjutnya, peneliti dapat menggunakan sampel yang lebih besar dalam ruang lingkup yang lebih luas sehingga hasil penelitian selanjutnya dapat menggambarkan kondisi dan digeneralisasikan pada ruang lingkup yang lebih luas. Penelitian selanjutnya juga dapat menambahkan variabel-variabel lain, seperti latar belakang keluarga, sikap terhadap kewirausahaan, norma subyektif, dan perilaku, yang mempengaruhi niat berwirausaha untuk memperdalam dan melengkapi hasil penelitian ini.

\section{DAFTAR PUSTAKA}

Ajzen, I. (1985). From Intentions to Actions: A Theory of Planned Behavior. Dalam J. Kuhl, \& J. Beckmann, Action Control (11-39). Berlin: Springer. 
(1991). The Theory of Planned Behavior. Organizational Behavior and Human Decision Processes 50(2), 179-211.

Aritonang R., L. R. (2007). Riset Pemasaran: Teori \& Praktik. Bogor: Penerbit Ghalia Indonesia.

Badan Pusat Statistik. (2018, 5 November). Keadaan Ketenagakerjaan Indonesia Agustus 2018. Berita Resmi Statistik No. 92/11/Th. XXI, 1-16. . (2018). Tingkat Pengangguran Terbuka Berdasarkan Kelompok Umur, 2015-2018 (Retrieved from: www.bps.go.id/10-3-2019). . (2019). Pengangguran Terbuka Menurut Pendidikan Tertinggi yang Ditamatkan 1986-2018 (Retrieved from: www.bps.go.id/11-3-2019).

Bosma, N., \& Kelley, D. (2018). Global Entrepreneurship Monitor: 2018/2019 Global Report. Chile: Gráfica Andes.

Fayolle, A., Gailly, B., \& Lassas-Clerc, N. (2006). Assessing the impact of entrepreneurship education programmes: a new methodology. Journal of European Industrial Training 30(9), 701-720.

Festiani, S. (2015, 12 Maret). Menkop Luncurkan Paket Kebijakan Pengembangan Wirausaha (Retrieved from: www.republika.co.id/8-3-2019).

Ghozali, I. (2013). Aplikasi Analisis Multivariate dengan Program IBM SPSS 21. Edisi 7. Semarang: Badan Penerbit Universitas Diponegoro.

Global Entrepreneurship Research Association. (2018). Global Entrepreneurship Monitor (GEM) Global Report 2017/18. Global Entrepreneurship Research Association.

Hasan, M., Khan, E. A., \& Nabi, N. U. (2017). Entrepreneurial education at university level and entrepreneurship development. Education + Training 59(7/8), 888-906.

Hendratno, E. T., \& Fitriati, R. (2015). The Study of Indonesia's Readiness to Cope with Demographic Bonus: A Review of Population Law. Journal of Indonesian Economy and Business 30(3), 195 - 219.

Herath, H. M., \& Rosli, M. (2014). Dimensions of Entrepreneurial Self-Efficacy and Firm Performance. Global Journal of Management and Business Research: A Administration and Management 14(4), 23-30.

Hisrich, R. D., Peters, M. P., \& Shepherd, D. A. (2013). Entrepreneurship. Ninth Edition. New York: McGraw-Hill Education.

International Bank for Reconstruction \& Development - World Bank. (2018). ASIA: Demography may not yield dividend. Oxford Analytica Daily Brief Service, 1.

International Labour Organization. (2016). Youth Employment Policy Summary: INDONESIA. International Labour Organization.

Joshi, A., Kale, S., Chandel, S., \& Pal, D. K. (2015). Likert Scale: Explored and Explained. British Journal of Applied Science \& Technology 7(4), 396-403.

Krueger, N. F., \& Carsrud, A. L. (1993). Entrepreneurial intentions: Applying the theory of planned behaviour. Entrepreneurship \& Regional Development 5(4), 315-330.

Kuratko, D. F. (2009). Introduction to Entrepreneurship: Eighth Edition. Canada: SouthWestern.

Liñán, F., \& Chen, Y.-W. (2009). Development and Cross-Cultural Application of a Specific Instrument to Measure Entrepreneurial Intentions. Entrepreneurship: Theory and Practice 33(3), 593-617. 
Naktiyok, A., Karabey, C. N., \& Gulluce, A. C. (2010). Entrepreneurial self-efficacy and entrepreneurial intention: the Turkish case. International Entrepreneurship and Management Journal 6(4), 419-435.

Paul, J., Hermel, P., \& Srivatava, A. (2017). Entrepreneurial intentions-theory and evidence from Asia, America, and Europe. Journal of International Entrepreneurship 15(3), 324-351.

Puni, A., Anlesinya, A., \& Korsorku, P. D. (2018). Entrepreneurial education, self-efficacy and intentions in Sub-Saharan Africa. African Journal of Economic and Management Studies 9(4), 492-511.

Sekaran, U., \& Bougie, R. (2017). Metode Penelitian untuk Bisnis. Edisi 6 - Buku 1. Jakarta: Salemba Empat.

Tsordia, C., \& Papadimitriou, D. (2015). The Role of Theory of Planned Behavior on Entrepreneurial Intention of Greek Business Students. International Journal of Synergy and Research 4(1), 23-37.

United States Census Bureau. (2019, 15 Maret). United States Census Bureau. Diambil kembali dari U.S. Census Bureau Current Population: https://www.census.gov/ popclock/print.php?component=counter tanggal 15 Maret 2019.

Wardi, R. (2018). Pemerintah Tingkatkan Pendidikan Kewirausahaan (Retrieved from: www.beritasatu.com/8-3-2019).

Yadav, A. (2017). University Support and Self-Efficacy as Predictors of Student Entrepreneurial Intentions: An Empirical Approach. AAYAM 7(2), 1-9. 